\title{
Efektivitas Dental Health Education Menggunakan Media Audio Visual dalam Meningkatkan Pengetahuan Siswa Sekolah Dasar
}

\author{
Anastasia D. Pitoy, Vonny N. S. Wowor, Michael A. Leman
}

\author{
Program Studi Pendidikan Dokter Gigi Fakultas Kedokteran Universitas Sam Ratulangi, \\ Manado, Indonesia \\ Email: pitoydominic@gmail.com
}

\begin{abstract}
Basic Health Research of the Ministry of Health of the Republic of Indonesia showed that $93 \%$ of Indonesian children experience dental caries. Dental health education (DHE) is the provision of information in the form of a comprehensive understanding of dental and oral health and the determinants that affect individuals and communities. Giving DHE to children must be done in an appropriate and effective way. This study was aimed to to determine the effectiveness of DHE using audio-visual media to elementary school students. This was a literature review study using the PubMed, Google Scholar, Science Direct, and Clinical Key databases. Then the literatures were selected according to the inclusion and exclusion criteria and a critical appraisal was carried out to obtain relevant and worthy literatures. After going through the study selection, nine literatures were accepted. All literatures showed an increase in students' knowledge about dental and oral health after the DHE using audio-visual media. In conclusion, elementary school students' knowledge about dental and oral health increased significantly after DHE using audiovisual media.
\end{abstract}

Keywords: dental health education (DHE); audio visual media; elementary school's students

\begin{abstract}
Abstrak: Hasil Riskesdas Kementrian Kesehatan Republik Indonesia menunjukkan 93\% anak Indonesia mengalami karies gigi. Dental health education (DHE) adalah pemberian informasi berupa pemahaman yang komprehensif tentang kesehatan gigi dan mulut serta faktor penentu yang memengaruhi individu dan komunitas. Pemberian DHE pada anak harus dilakukan dengan cara yang tepat dan efektif. Penelitian ini bertujuan untuk mengetahui efektivitas dental health education menggunakan media audio visual pada siswa sekolah dasar. Jenis penelitian ialah suatu literature review mengguanakan database PubMed, Google Scholar, Science Direct, dan Clinical Key. Literatur yang diperoleh kemudian diseleksi sesuai dengan kriteria inklusi dan eksklusi serta dilakukan critical appraisal untuk mendapat literatur yang relevan dan layak diteliti. Setelah melalui seleksi studi, didapatkan sembilan literatur untuk diulas. Semua literatur menunjukkan terjadi peningkatan pengetahuan siswa tentang kesehatan gigi dan mulut setelah DHE menggunakan media audio visual. Simpulan penelitian ini ialah pengetahuan siswa sekolah dasar tentang kesehatan gigi dan mulut meningkat secara bermakna setelah pemberian DHE menggunakan media audio visual.
\end{abstract}

Kata kunci: dental health education (DHE); media audio visual; siswa sekolah dasar

\section{PENDAHULUAN}

Kesehatan gigi dan mulut merupakan komponen penting dari kesehatan tubuh individu secara umum. Kesehatan gigi dan mulut adalah keadaan sehat yang mencakup kemampuan untuk berbicara, tersenyum, mencium, merasakan, menyentuh, mengu- nyah, menelan, dan menyampaikan berbagai ekspresi wajah dengan percaya diri dan tanpa rasa sakit, ketidaknyamanan dan penyakit kompleks kraniofasial. Pelayanan kesehatan gigi dan mulut dilaksanakan kepada individu di segala usia melalui pendekatan siklus hidup. Dengan demikian, anak-anak juga 
mempunyai hak untuk mendapatkan pelayanan kesehatan gigi dan mulut. Gangguan yang terjadi pada kesehatan gigi dan mulut dapat membawa dampak negatif pada kehidupan sehari-hari, seperti menurunnya kesehatan secara umum, menurunkan kepercayaan diri, mengganggu performa dan kehadiran di sekolah bagi anak. ${ }^{1-3}$

The Global Burden of Disease Study 2016 menyatakan bahwa masalah kesehatan gigi dan mulut khususnya karies gigi merupakan penyakit yang dialami hampir setengah dari populasi penduduk dunia (3,58 milyar jiwa). Hasil Riset Kesehatan Dasar (Riskesdas) tahun 2018 menunjukkan bahwa 57,6\% masyarakat Indonesia mengalami masalah gigi dan mulut, dan hanya $10,2 \%$ yang mendapatkan pelayanan dari tenaga medis gigi. Terdapat $93 \%$ anak Indonesia mengalami karies gigi. ${ }^{3,4}$

Pemberian edukasi dapat menjadi salah satu cara untuk meningkatkan pengetahuan kesehatan gigi dan mulut untuk mencegah timbulnya masalah kesehatan gigi dan mulut. sendiri. Dental health education (DHE) adalah pemberian informasi berupa pemahaman yang komprehensif tentang kesehatan gigi dan mulut serta faktor penentu, berbagai metode, dan membutuhkan rencana tindakan yang tepat oleh semua pihak. Salah satu cara yang dipakai dalam DHE ialah menggunakan media audio visual. ${ }^{5,6}$

Media merupakan sarana untuk menyalurkan pesan dari pemberi pesan kepada penerima pesan baik berupa perangkat keras ataupun perangkat lunak. Media audio visual termasuk dalam multimedia yang mengandung unsur suara dan gambar pada waktu bersamaan. Pemberian edukasi menggunakan media audio visual ditangkap individu dengan dua alat indera, yaitu telinga untuk audio, dan mata untuk visual. Menurut Dale's Cone Experience, dengan cara melihat dan mendengar, dapat menambah pengaruh kepada objek sebesar $50 \% .^{5,7}$

Kemajuan zaman yang semakin berkembang membuat media sosial telah menjadi sarana komunikasi yang digunakan sebagian besar orang. Media sosial juga dapat digunakan sebagai sarana pendukung pembelajaran. Media audio visual dan media sosial sangat berkaitan. Oleh karena itu, seiring dengan perkembangan zaman, media audio visual berperan penting dalam edukasi kesehatan bukan hanya untuk ditayangkan secara langsung, melainkan dapat juga disebarluaskan. ${ }^{5-8}$

Berdasarkan latar belakang yang dipaparkan maka penulis tertarik untuk melakukan studi pustaka terkait efektivitas dental health education menggunakan media audio visual dalam meningkatkan pengetahuan siswa sekolah dasar.

\section{METODE PENELITIAN}

Penelitian ini bertujuan untuk mengetahui efektivitas DHE menggunakan media audio visual pada subjek penelitian yaitu siswa sekolah dasar. Penelitian ini merupakan suatu literature review dengan menggunakan empat database yaitu PubMed, Google Scholar, Science Direct, dan Clinical Key. Literatur yang diperoleh kemudian diseleksi sesuai dengan kriteria inklusi dan eksklusi serta dilakukan critical appraisal untuk mendapat literatur yang relevan dan layak diteliti.

\section{HASIL PENELITIAN}

Pencarian literatur dilakukan dengan menggunakan empat databasae PubMed, Google Scholar, Science Direct, dan Clinical Key. Tabel 1 memperlihatkan hasil pencarian literatur penelitian; yang terbanyak diperoleh ialah 1730 artikel dari Google Scholar, disusul 44 artikel dari Clinical Key, 31 artikel dari PubMed, dan 1 artikel dari Science Direct. Setelah melalui seleksi studi, didapatkan sembilan literatur untuk diulas. Dental health education dinilai efektif jika terjadi perbedaan atau peningkatan antara nilai pre-test dan post-test pada sampel penelitian.

Setiap artikel yang diulas menggunakan metode penelitian quasi experimental, di mana pre-test dan post-test dilakukan terhadap kelompok yang akan diteliti dan kelompok kontrol. Tabel pengulasan artikel dapat diakses melalui link:http://ringkas. kemdikbud.go.id/tabelpengulasan. 
Tabel 1. Hasil pencarian literatur menggunakan empat database

\begin{tabular}{|c|c|}
\hline Mesin Pencari & Strategi Pencarian \\
\hline PubMed & $\begin{array}{l}\text { ('dental health education') AND ('audio visual') } \\
\text { Hasil pencarian: } 31 \text { artikel }\end{array}$ \\
\hline Google Scholar & $\begin{array}{l}\text { "dental health education" AND "audio-visual media" } \\
\text { Hasil pencarian: } 1730 \text { artikel } \\
\text { "dental health education" AND "media audio visual" } \\
\text { Hasil pencarian: } 48 \text { artikel }\end{array}$ \\
\hline Science Direct & $\begin{array}{l}\text { ("dental health education OR "oral health education") } \\
\text { AND ("audio visual media") } \\
\text { Hasil pencarian: } 1 \text { artikel }\end{array}$ \\
\hline Clinical Key & $\begin{array}{l}\text { dental health education AND audiovisual media } \\
\text { Hasil pencarian: } 44 \text { artikel }\end{array}$ \\
\hline
\end{tabular}

Literatur pertama oleh Papiliya et $\mathrm{al}^{9}$ yang meneliti efektivitas media audio visual terhadap perilaku kesehatan gigi dan mulut siswa Sekolah Dasar dengan media audio sebagai kelompok kontrol. Hasil uji paired $t$-test menunjukkan nilai $\mathrm{p}=0,000 \quad(<0,05)$ untuk media audio visual yang berarti terdapat perbedaan dari hasil pre-test dan post-test. Berdasarkan uji independent $t$ test, didapatkan perbedaan bermakna dari selisih jumlah skor antara pemberian DHE menggunakan media audio visual dengan media audio dalam meningkatkan perilaku pemeliharaan kesehatan gigi dan mulut dengan nilai $\mathrm{p}=0.004(<0.05)$.

Literatur kedua oleh Kantohe et al ${ }^{10}$ yang membandingkan media audio visual dalam bentuk video dengan flip chart. Sampel penelitiannya ialah siswa SD berusia 10-11 tahun berjumlah 64 sampel yang terbagi atas kelompok video dan kelompok kontrol. Hasil uji statistik Wilcoxon menunjukkan nilai $\mathrm{p}=0,000$ $(<0,05)$ yang berarti terdapat perbedaan hasil pengukuran tingkat pengetahuan pada kedua media ini. Namun hasil uji MannWhitney menunjukkan bahwa terdapat perbedaan bermakna mengenai selisih jumlah skor antara media video dan flip chart dengan nilai $\mathrm{p}=0,007$. Data ini menunjukkan bahwa efektivitas media video lebih besar dibandingkan kelompok flip chart.

Literatur ketiga oleh Amelia et $\mathrm{al}^{11}$ yang membandingkan pemberian DHE menggunakan video dan peragaan sebagai kelompok kontrol. Hasil penelitian disaji- kan dalam bentuk skoring kuisioner. Uji statistik paired t-test dilakukan dengan hasil nilai $\mathrm{p}=0,001$ pada kedua metode yang berarti terdapat perbedaan pada hasil pretest dan post-test yang menunjukkan bahwa keduanya efektif dalam meningkatkan pengetahuan penyikatan gigi pada anak. Hasil penelitian ini juga menunjukkan bahwa metode peragaan lebih efektif dibandingkan metode video namun tidak terdapat perbedaan bermakna antara kedua metode yang ditunjukkan oleh hasil uji statistik independent $t$-test $(\mathrm{p}=0,365)$.

Literatur keempat oleh Tandilangi et $\mathrm{al}^{12}$ yang membahas tentang efektivitas DHE menggunakan video animasi pada siswa SD. Hal yang membedakan penelitian ini dengan yang lain yaitu post-test dilakukan dua kali. Hasil uji Wilcoxon menunjukkan nilai $\mathrm{p}=0,000(<0,05)$ yang berarti terdapat peningkatan skor nilai rerata pada kelompok animasi kartun.

Literatur kelima oleh Satria dan Fatmasari ${ }^{13}$ yang membandingkan pemberian DHE menggunakan media online "mogigu" dengan kelompok kontrol menggunakan phantom. Sampel penelitiannya ialah siswa SD berumur 10-11 tahun, masing-masing 35 sampel di tiap kelompok. Hasil penelitian terbagi atas kategori baik, cukup, dan kurang. Hasil uji statistik Wilcoxon menunjukkan nilai $\mathrm{p}=0,000$ $(<0,05)$ yang berarti terdapat perbedaan pengetahuan siswa sebelum dan sesudah pemberian DHE menggunakan media online "mogigu". Hasil uji Mann Whitney 
mendapatkan nilai $\mathrm{p}=0,000(<0,05)$ yang berarti media online "mogigu" lebih efektif dibandingkan dengan media phantom.

Literatur keenam oleh Setiawan et $\mathrm{al}^{14}$ yang meneliti pengaruh DHE dengan media motion graphic terhadap pengetahuan tentang karies pada siswa kelas IV. Meski tercantum menggunakan metode quasi experimental, penelitian ini tidak mempunyai kelompok kontrol untuk membandingkan efektivitas media yang digunakan. Sampel penelitian ini berjumlah 66 siswa. Uji statistik paired $t$-test menghasilkan nilai $\mathrm{p}=0,000 \quad(<0,05)$ yang berarti terdapat pengaruh DHE menggunakan media video motion graphic terhadap pengetahuan tentang karies gigi murid kelas IV di SD.

Literatur ketujuh oleh Sari et al ${ }^{15}$ yang meneliti pengaruh edukasi film dengan perilaku menggosok gigi pada anak usia 6-8 tahun. Berbeda dengan penelitian lainnya, penelitian Sari et al bukan hanya menilai menggunakan kuisioner, tetapi juga menggunakan lembar observasi untuk menilai psikomotor. Peningkatan pengetahuan yang terjadi diuji menggunakan uji statistik Wilcoxon dan didapatkan nilai $\mathrm{p}=0,000$ $(<0,05)$ yang berarti terdapat perbedaan pengetahuan pada anak usia 6-8 tahun sebelum dan sesudah diberi DHE menggunakan media film.

Literatur kedelapan oleh Fastabiqul dan Prasko yang meneliti tentang perbedaan pengaruh penyuluhan menggunakan media video dan boneka tangan sebagai kelompok kontrol. Uji statistik Mann Whitney menunjukkan nilai $\mathrm{p}=0,465(>0,05)$ yang berarti tidak terdapat perbedaan bermakna antara media video dan boneka tangan dalam peningkatan pengetahuan siswa SD.

Literatur kesembilan oleh Sanjaya et al ${ }^{17}$ untuk melihat perbandingan pemberian DHE menggunakan media video dan simulasi. Sampel yang digunakan ialah siswa SD berusia 12 tahun. Uji statistik yang digunakan ialah paired $t$-test yang menghasilkan nilai $\mathrm{p}=0,000(<0,05)$ untuk kedua metode. Hal ini berarti terdapat perbedaan bermakna terhadap keterampilan menyikat gigi siswa sebelum dan sesudah pemberian DHE menggunakan media audio visual dan simulasi. Namun hasil independent t-test menunjukkan nilai $>0,05$ yang berarti tidak terdapat perbedaan bermakna antara metode simulasi dan media audio visual.

\section{BAHASAN}

Efektivitas pemberian DHE menggunakan media audio visual dinilai dari apakah terjadi peningkatan hasil pre-test dan posttest yang dilakukan. Dental health education adalah upaya dalam memfasilitasi individu atau kelompok untuk mengetahui dan mengadopsi cara menjaga kesehatan gigi dan mulut serta mendorong dalam dalam perilaku kesehatan yang bersifat preventif. ${ }^{18}$.

Keenam literatur yang diulas pada penelitian ini menggunakan penyajian data hasil pre-test dan post-test yang berbedabeda. Namun pada setiap literatur jelas tercantum perubahan tingkat pengetahuan sebelum dan sesudah diberi DHE menggunakan audio visual. Hasil penelitian yang dipaparkan dalam bentuk kategori didapatkan pada penelitian Papiliya et al serta Satria dan Fatmasari. ${ }^{9,13}$ Hasil penelitian yang dipaparkan dalam bentuk skor/kuisioner skoring dilaporkan pada penelitian Kantohe et al, Nurfalah et al, dan Tandilangi et al. ${ }^{10-}$

12 Namun, pada literatur yang diteliti oleh Tandilangi et $\mathrm{al}^{12}$ terdapat dua tahap posttest, yaitu post-test pertama dan kedua. Hasil penelitian yang dipaparkan dalam mean terdapat pada penelitian Setiawan et al. ${ }^{14}$

Setiap literatur mengemukakan bahwa terjadi peningkatan pengetahuan siswa setelah diberi DHE menggunakan media audio visual. Alat audio visual merupakan alat yang dapat didengar dan dapat dilihat pada waktu yang bersamaan. Pemanfaatan indra pendengaran dan penglihatan dalam menerima pesan yang disampaikan dalam pemberian DHE menjadi salah satu keunggulan media audio visual. ${ }^{19,20}$ Penelitian Papiliya et $\mathrm{al}^{9}$ dan Tandilangi et $\mathrm{al}^{12}$ mengemukakan bahwa DHE menggunakan media audio visual lebih efektif dibandingkan audio dan tanpa alat bantu. Kedua penelitian tersebut sesuai dengan teori yang dikemukakan Edgar Dale dalam Cone of Experience yaitu dengan melihat dan 
mendengar, presentase edukasi yang dapat ditangkap oleh siswa mencapai 50\%. Angka ini lebih tinggi daripada dengan hanya melihat atau hanya mendengar materi yang disampaikan. ${ }^{21}$ Fastabiqul dan Prasko $^{16}$ mengemukakan media video lebih efektif daripada media boneka tangan meskipun keduanya memanfaatkan alat indra yang sama yaitu mata dan telinga. Demikian pula Kantohe et $\mathrm{al}^{10}$ yang mengemukakan hal serupa yaitu media video lebih efektif dibandingkan media flip chart yang dipaparkan sambil dijelaskan oleh edukator. Kedua media ini juga memanfaatkan alat indra penglihatan dan pendengaran secara bersamaan. Adapun penelitian yang dilakukan oleh Sanjaya et $\mathrm{al}^{17}$ mengemukakan bahwa tidak terdapat perbedaan bermakna antara pemberian DHE menggunakan media video dan simulasi meskipun media simulasi memanfaatkan lebih dari dua alat indra. Hal-hal tersebut dikarenakan media audio visual menarik bagi anak sehingga dapat meningkatkan atensi anak. Media audio visual menggunakan rangkaian kata yang mudah dipahami anak dan dipadukan dengan berbagai warna yang sangat berpengaruh pada ingatan anak dan perhatian visual mereka.

Teori belajar behavioristik merupakan teori belajar perubahan tingkah laku yang terjadi karena pengalaman yang dialami pesertanya. Teori ini mengemukakan bahwa stimulus sangat berperan penting dalam memberikan pengalaman sebagai input yang dapat diadopsi oleh peserta sehingga menciptakan output berupa respon yang positif. ${ }^{22}$ Media audio visual memiliki berbagai keunggulan sebagai stimulus dalam pembelajaran. Gerakan yang dapat dilihat oleh siswa disertai dengan suara yang dapat didengar merupakan rangsangan yang serasi dan mudah diterima oleh siswa.

Efek-efek dalam media audio visual merupakan aspek pelengkap namun sangat penting dalam menambah atensi siswa sehingga siswa dapat memberi perhatian yang lebih terhadap edukasi yang diberikan. Dengan stimulus yang disukai siswa, maka edukasi dapat diterima dengan baik melalui indra pendengaran dan penglihatan sehing- ga siswa dapat mengaplikasikan apa yang dipelajari melalui media audio visual ke dalam perilakunya di kehidupan seharihari. ${ }^{19}$

Media audio visual lebih mudah dan nyaman untuk diakses serta sangat sering ditemukan di berbagai tempat seperti internet, televisi, dan media elektronik lainnya. Satria dan Fatmasari ${ }^{13}$ melakukan penelitian untuk melihat efektivitas media online "mogigu" dalam kegiatan dental health education. "Mogigu" adalah inovasi dental health education menggunakan audio visual dalam penyajiannya yang bisa diunggah di youtube.

Selain itu DHE dengan menggunakan media film dan video motion graphic juga efektif dalam meningkatkan pengetahuan siswa SD tentang kesehatan gigi dan mulut yang dibuktikan lewat penelitian oleh Sari et $\mathrm{al}^{15}$ dan Setiawan et $\mathrm{al}^{14}$. Media film dinilai dapat merangsang pikiran, perasaan, perhatian, dan minat siswa dalam belajar untuk memperoleh pengetahuan, sikap, dan psikomotor sehingga dapat dikatakan efektif dalam pemberian DHE. Video motion graphic memanfaatkan animasi berupa karakter manusia, gigi dan kuman yang dapat bergerak serta menjelaskan makanan yang baik dan kurang baik dengan cara yang menarik. ${ }^{14}$

Pemberian DHE menggunakan media audiovisual yang memanfaatkan media digital tidak dibatasi dengan keterbatasan pertemuan tatap muka dan akses. Pemberian edukasi ini dapat dilaksanakan di rumah dan membantu orang tua dalam mengedukasi anak tentang kesehatan gigi dan mulut. Akses yang dapat dimanfaatkan untuk pemberian DHE menggunakan audio visual dapat berupa media sosial seperti instagram, youtube, whatsapp s dan sebagainya. Akses yang mudah dijangkau oleh guru dan orang tua dapat mempermudah pemberian DHE untuk meningkatkan pengetahuan siswa tentang kesehatan gigi dan mulut serta membawa pada perilaku kesehatan yang lebih baik.

\section{SIMPULAN}

Pengetahuan siswa sekolah dasar tentang kesehatan gigi dan mulut meningkat 
secara bermakna setelah pemberian dental health education menggunakan media audio visual.

\section{Konflik Kepentingan}

Penulis menyatakan tidak terdapat konflik kepentingan dalam studi ini.

\section{DAFTAR PUSTAKA}

1. Kementerian Kesehatan RI. Peraturan Menteri Kesehatan No. 89 tahun 2015 tentang upaya kesehatan gigi dan mulut. [cited 2021 Mar 19]. Available from URL: www.peraturan.go.id

2. Glick M, Williams DM, Kleinman DV, Vujicic M, Watt RG, Weyant RJ. A new definition for oral health developed by the FDI World Dental Federation opens the door to a universal definition of oral health. J Am Dent Assoc. 2016;147: 915-7.

3. Kementerian Kesehatan RI. Pusat Data Informasi Kementrian Kesehatan RI. Jakarta: Kemenkes RI, 2019; p. 2.

4. Kementrian Kesehatan RI Badan Penelitian dan Pengembangan. Hasil Utama Riskesdas 2018. Jakarta: Kemenkes RI, 2018; p. 61-96.

5. Fujiyanto A, Kurnia Jayadinata A, Kurnia D, Studi P, Upi P, Sumedang K, et al. Penggunaan media audio visual untuk meningkatkan hasil belajar siswa pada materi hubungan antar makhluk hidup. Jurnal Pena Ilmiah. 2016;1(1):2-4.

6. Burt BA, Eklund SA. Dentistry, Dental Practice, and the Community. St. Louis. Elsevier Saunders; 2005.

7. Anderson HM. Dale's Cone of Experience [Internet]. [cited 2021 April 13]. Available from URL: https://www. queensu.ca/teachingandlearning/modul es/active/documents/Dales_C one_of_Experience_summary.pdf

8. Arnett ME, Loewen JM, Romito LM. Use of social media by dental educators. J Dent Educ. 2013;77(11):9-10.

9. Papiliya EA, Kustina Z, Juliatri. Perbandingan pengaruh promosi kesehatan menggunakan media audio dengan media audiovisual terhadap perilaku kese-hatan gigi dan mulut siswa SD. e-GiGi. 2016;4(2): $1-4$.

10. Kantohe ZR, Wowor VNS, Gunawan PN. Perbandingan efektivitas pendidikan kesehatan gigi menggunakan media video dan flip chart terhadap peningkatan pengetahuan kesehatan gigi dan mulut anak. e-GiGi. 2016;4(2):1-6.

11. Nurfalah A, Yuniarrahmah E, Aspriyanto D. Efektivitas metode peragaan dan metode video terhadap pengetahuan penyikatan gigi pada anak usia 9-12 tahun di SDN Keraton 7 Martapura. Dentino. 2014;2(2):1-5

12. Tandilangi $\mathrm{M}$, Mintjelungan $\mathrm{CN}$, Wowor VNS. Efektivitas dental health education dengan media animasi kartun terhadap perubahan perilaku kesehatan gigi dan mulut siswa SD Advent 02 Sario Manado. e-GiGi. 2016;4(2):1-4

13. Satria J, Fatmasari D. Media online "Mogigu" effective for increasing knowledge about toothbrushing on elementary school. Jurnal Riset Kesehatan. 2020; 9(2):1-4.

14. Setiawan MD, Rahmawati I, Rasuna U. Pengaruh penyuluhan kesehatan gigi dengan media video motion graphic terhadap pengetahuan tentang karies gigi pada murid kelas IV A dan IV B di SDN Indrasari 1 Martapura. Jurnal Terapis Gigi dan Mulut. 2020;1(2):1-4.

15. Sari NNRP, Purwanti IS, Juanamasta IG. edukasi film terhadap perilaku menggosok gigi pada anak usia 6-8 tahun. Jurnal Kesehatan Masyarakat. 2019; 9(2):1-6.

16. Fastabiqul H, Prasko. Perbedaan pengaruh penyuluhan menggunakan media video dan boneka tangan terhadap peningkatan pengetahuan kesehatan gigi dan mulut pada siswa sekolah dasar. Jurnal Kesehatan Gigi. 2018; 5(2):1-5.

17. Sanjaya AN, Suwargiani AA, Wardani R. Comparison between audio-visual media and simulation on the toothbrushing skills of elementary school students. Padjajaran Journal of Dentistry. 2019;31(3):1-5

18. Mason J. Concepts in Dental Public Health (2nd ed). China: Lippincott Williams \& Wilkins Health, 2010.

19. Tirtoni F. Buku Utuh Media dan Teknologi Pembelajaran Terpadu di Sekolah Dasar. Sidoarjo: Umsida Press, 2018.

20. Cahyadi A. Pengembangan Media dan Sumber Belajar Teori dan Prosedur. Serang Baru: Laksita Indonesia, 2019; p. 113.

21. Shaaruddin J, Mohamad M. Identifying the effectiveness of active learning strate- 
gies and benefits in curriculum and pedagogy course for undergraduate TESL students. Creative Education. 2017;8(14):3-4.
22. Rusli RK, Kholik MA. Teori belajar dalam psikologi pendidikan. Jurnal Sosial Humaniora. 2013;4(2):2-3. 